\title{
PENGGUNAAN SISTEM KOMPUTERISASI PADA KINERJA PROCUREMENT DEPARTMENT DI GOLD BRIDGE SHIPPING LTD
}

\author{
Fiasinta, O.I.S ${ }^{\text {a }}$ Purwantini, $\mathbf{S}^{\mathrm{b}}$ \\ ${ }^{a}$ Taruni Prodi KALK Politeknik Ilmu Pelayaran Semarang, \\ ${ }^{b}$ Dosen Prodi KALK Politeknik Ilmu Pelayaran Semarang.
}

\begin{abstract}
Indonesia dikelilingi beberapa negara maju dengan sistem teknologi canggih dan terstruktur, yang mempengaruhi teknologi di Indonesia. Demikian juga suatu organisasi perusahaan terdapat banyak aset penting dan harus dicatat dengan rinci serta diolah secara tepat sehingga dibutuhkan penggunaan sistem komputerisasi. Pada era pelayanan prima, Gold Bridge Shipping Ltd harus memberikan pelayanan yang cepat, terbuka, dan professional kepada mitra-mitra kerjanya. Oleh karena itu, proses purchasing harus menggunakan teknologi informatika agar proses pelayanan procurement terlaksana dengan sitematis. Namun sayangnya sistem komputerisasi belum seluruhnya diterapkan di Procurement Department sehingga menghambat kegiatan di Procurement department. Penelitian ini bertujuan untuk mengetahui perbandingan kinerja Procurement Department menggunakan dan tidak menggunakan sistem komputerisasi. Metode penelitian yang digunakan yaitu kualitatif deskriptif. Adapun sumber data yang digunakan yaitu riset pustaka, wawancara dan dokumentasi. Hasil penelitian ini menemukan beberapa kendala yang dihadapi dalam penggunaan sistem komputerisasi diantaranya spesifikasi komputer yang belum diperbarui, gangguan sistem computer, gangguan system Manajemen database kerusakan komponen komputer, dan kurangnya SDM.
\end{abstract}

\section{Kata Kunci : Sistem Komputerisasi, Kinerja, Procurement Department}

\section{PENDAHULUAN}

Indonesia dikelilingi beberapa negara maju dengan sistem teknologi yang canggih dan terstruktur, yang mempengaruhi perkembangan teknologi di Indonesia. Demikian juga dalam suatu organisasi perusahaan terdapat banyak aset yang sangat penting yang harus tercatat dengan rinci dan diolah secara tepat sehingga dibutuhkan penggunaan sistem komputerisasi di berbagai departmen perusahaan. Hal ini akan membantu bilamana terjadi sesuatu kesalahan dan mempermudah pengawasan berkas. Namun sayangnya, sebagian perusahaan pelayaran di Indonesia belum menggunakan sistem komputerisasi.

Salah satu contohnya di perusahaan Gold Bridge Shipping Ltd. Gold Bridge Shipping Ltd (GBS) didirikan di Hong Kong pada tahun 1990, dan sejak Agustus 2016 membuka kantor perwakilannya di Jakarta sebagai Ship Management Company, yang menawarkan berbagai layanan manajemen kapal tanker untuk minyak, kimia dan gas. Dan memiliki beberapa departemen yang mendukung kegiatan operasional perusahaan. Dimana setiap departemen mempunyai keterkaitan satu sama lain termasuk di Procurement Department yang mempunyai keterkaitan dengan Technical Department dan Accounting Department.

Pada era pelayanan prima, Gold Bridge Shipping Ltd harus memberikan pelayanan yang cepat, terbuka, dan professional kepada mitramitra kerjanya. Dengan tujuan peningkatan pelayanan tersebut, pada proses purchasing (pengadaan barang) dan jasa tidak sebatas pada pemilihan rekanan proyek dengan bagian pembelian (purchasing) atau perjanjian resmi kedua belah pihak, namun mencakup seluruh proses sejak awal perencanaan, persiapan, perijinan, penentuan pemenang tender, tahap pelaksanaan dan proses administrasi dalam pengadaan barang dan jasa sehingga teknologi komputer sangat dibutuhkan agar proses pelayanan procurement dapat terlaksana dengan sistematis. Tetapi walaupun Gold Bridge Shipping Ltd merupakan perusahaan yang sudah terstruktur namun ada beberapa kendala yang ditemukan di lapangan selama penulis melaksanakan praktek darat yaitu salah satunya kurangnya sistem komputerisasi yang handal sehingga menghambat kegiatan di Procurement Department. Dari fakta ini penulis merasa perlu meneliti sejauh mana pentingnya sistem komputerisasi pada kinerja Procurement Department. 
Dari latar belakang diatas ditemukan rumusan masalah yang dikemukakan oleh peneliti:

1. Bagaimana kinerja Procurement Department dengan menggunakan sistem komputerisasi?

2. Bagaimana kinerja Procurement Department dengan tidak menggunakan sistem komputerisasi?

3. Bagaimana perbandingan kinerja Procurement Department menggunakan sistem komputerisasi dan tidak menggunakan sistem komputerisasi?

\section{LANDASAN TEORI}

\section{A. Tinjauan Pustaka}

\section{Sistem Komputerisasi}

Definisi sebuah sistem komputerisasi mempunyai peranan yang sangat penting di dalam pendekatan untuk mempelajari sebuah sistem komputerisasi. Setiap definisi yang dikemukakan para ahli pastilah sudah mengalami pengujian yang dapat dipertanggungjawabkan, seperti yang dijelaskan Fakhri Husein \& Amin Wibowo (2011:4), Istilah komputer mempunyai arti luas dan berbeda. Istilah komputer diambil dari bahasa latin Computere yang berarti menghitung (to compute atau reckon). Juliandi (2009:1) juga menjelaskan bahwa pengertian komputer yaitu berasal dari Bahasa Inggris "computer" yang artinya alat penghitung atau alat yang digunakan manusia untuk menghitung. Dari pernyataan diatas dapat disimpulkan komputerisasi adalah Pemakaian komputer sebagai alat bantu penyelesaian tugas sebagai pengganti penyelesaian pekerjaan secara manual. Komputerisasi juga dapat diartikan sebagai Penggunaan komputer (dalam menghitung, mengolah data, dan sebagainya) Elemen-elemen yang saling berhubungan membentuk satu kesatuan untuk melasanakan pengolahan data untuk menghasilkan informasi dengan menggunakan perangkat komputer. Elemen-elemen tersebut adalah ; Hardware (Perangkat Keras) yaitu komputer itu sendiri, Software (Perangkat Lunak) yaitu program yang berisi perintah untuk melakukan proses tertentu dan Brainware yaitu manusia yang terlibat didalam mengoperasikan serta mengatur sistem komputer

2. Pengertian Kinerja

Kinerja menurut Malayu S.P Hasibuan (2014:34) mengemukakan kinerja (prestasi kerja) adalah sesuatu hasil kerja yang dicapai seseorang dalam melaksanakan tugas-tugas yang dibebankan kepadanya yang didasarkan atas kecakapan, pengalaman dan kesungguhan serta waktu.

Menurut Fahmi (2012:2), Kinerja adalah hasil yang diperoleh oleh suatu organisasi baik organisasi tersebut bersifat profit oriented dan non profit oriented.

Berdasarkan definisi yang sudah disebutkan bahwa kegiatan paling penting untuk memajukan karier dalam perusahaan adalah kinerja ( prestasi kerja) yang baik, karena hal ini mendasari semua kegiatan pengembangan karier lainnya Kemajuan karier sangat tergantung pada kinerja ( prestasi kerja).

\section{Procurement Department}

Procurement (pengadaan) merupakan pembelian barang dan jasa oleh perusahaan (Turban, 2010:231). Pada perusahaan terdapat prosedur pengadaan dalam panduan manajemen keselamatannya. Prosedur pengadaan ini bertujuan untuk menggambarkan tanggung jawab dan tindakan yang diperlukan, untuk memastikan bahwa barang, alat, material atau jasa yang dibeli sesuai dengan ketentuan khusus perusahaan dan bahwa pemasok/sub-kontraktor diawasi, disetujui dan dievaluasi oleh perusahaan. Sedangkan menurut Moekijat dalam kamus manajemen (2009:128) menyebutkan bahwa " Departmen menunjukan suatu bidang, bagian atau cabang tertentu dari suatu perusahaan, atas nama seorang manajer yang mempunyai kekuasaan untuk pelaksanaan daripada kegiatan-kegiatan tertentu."

Tugas pokok Procurement Department yaitu : Menerima daftar permohonan barang atau jasa yang telah di periksa dan disetuji oleh manajer atau pengawas. Mengirimkan permintaan barang (Requisition) sesuai daftar minimal kepada tiga pemasok (supplier), meminta kesediaan mereka,waktu pengiriman dan penetapan harga. Melakukan pendekatan dengan pemasok (Supplier) atau sub-kontraktor yang ada dalam daftar perusahaan sebagai dasar pemilihan berdasarkan kualitas dan ketersediaan barang, suku cadang atau jasa, keahlian, harga, ketersediaan dan waktu pengiriman serta lokasi pengiriman. Mempersiapkan "Purchase Order" atau dokumen yang dibuat untuk menyatakan barang yang benar-benar akan dibeli sesuai dengan harga dan spesifikasi yang disepakati. Kemudian diperiksa silang dan ditandatangani oleh Manajer Procurement, Manajer Technical Fleet, dan Tecnical Direktur. Mengirim 
"Payment Voucher" yang telah disahkan kepada Accounting Department.

Perusahaan-perusahaan menggunakan metode Procurement yang berbeda-beda dalam memperoleh produk dan jasa, tergantung apa dan dimana mereka membeli, kuantitas dan kualitas, dan berapa jumlah uang yang terpakai. Metode-metode yang terutama dari Procurement menurut Turban (2010:251) , yaitu dengan cara:Metode membeli manufaktur, penjual grosir, atau pengecer dari katalogkatalog mereka dan adanya negosiasi, kemudian metode membeli melalui katalog yang terhubung dengan memeriksa katalog penjual atau membeli melalui mal-mal industri. Adapun juga metode membeli melalui katalog pembeli internal dimana perusahaan menyetujui katalogkatalog vendor termasuk kesepakatan harga, pendekatan ini digunakan untuk memesan barang secara langsung kepada vendor. Mengadakan penawaran tender dari sistem dimana pemasok bersaing dengan yang lainnya. Metode ini digunakan untuk pembelian dalam jumlah besar. Membeli dari situs pelelangan umum atau privasi dimana organisasi berpartisipasi sebagai salah satu pembeli Bergabung dengan suatu kelompok sistem pembeli dimana memeriksa permintaan partisipasi, menciptakan jumlah besar kemudian kelompok ini dapat menegosiasikan harga atau menginisiasikan proses tender.

\section{B. Kerangka Pikir}

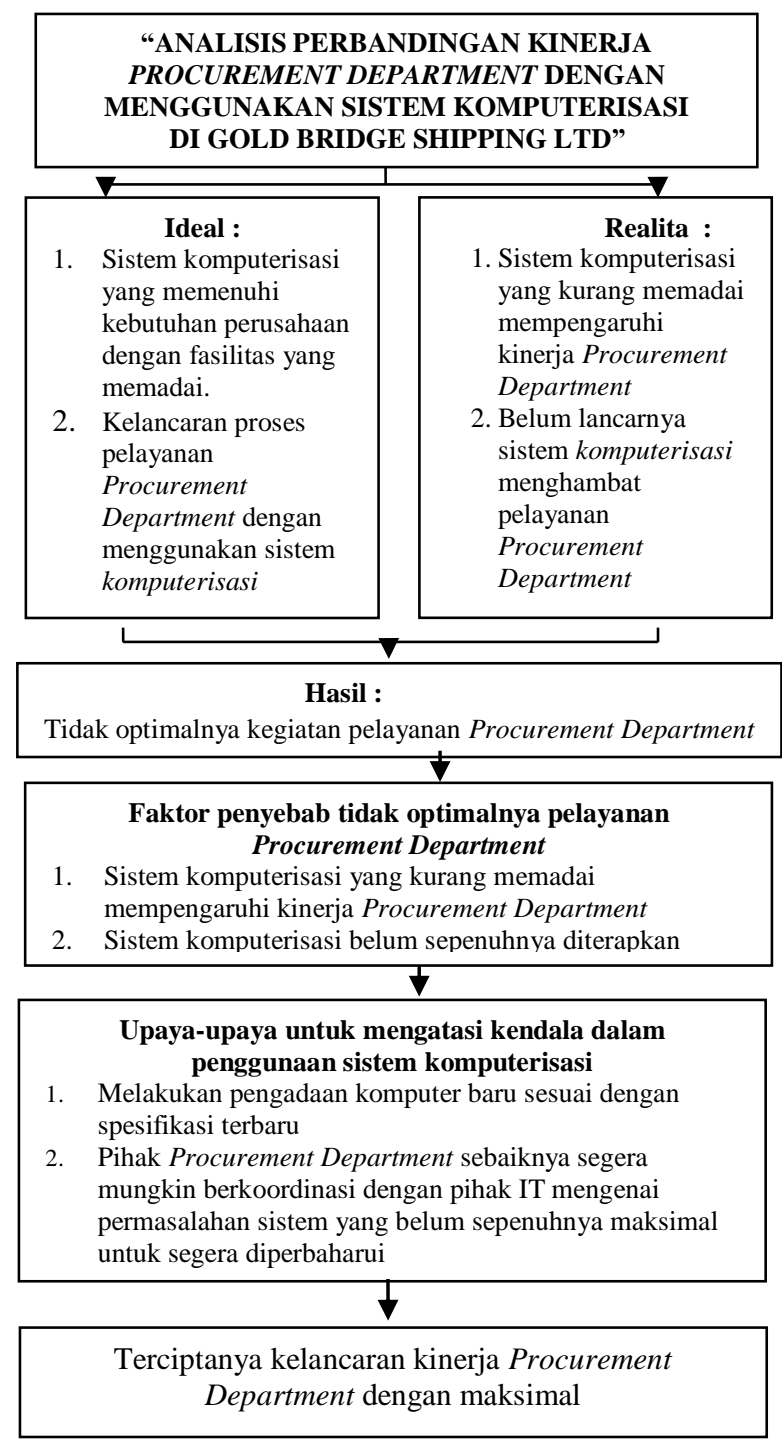

Gambar Kerangka Pikir

\section{METODE PENELITIAN}

Metode penelitian merupakan hal penting dalam Penelitian, hal ini dikarenakan baik buruknya suatu penelitian tergantung dari metode yang digunakan. Ditinjau dari jenis datanya pendekatan yang digunakan dalam penelitian ini adalah pendekatan kualitatif. Yang dimaksud penelitian kualitatif menurut Lexy J. Moleong (2015:6), penelitian kualitatif adalah penelitian yang bermaksud untuk memahami fenomena tentang apa yang dialami oleh subjek penelitian misalnya perilaku, persepsi, motivasi, tindakan dan lain-lain,

Adapun jenis pendekatan penelitian ini adalah deskriptif, yaitu penelitian yang berusaha untuk menuturkan pemecahan masalah yang ada 
sekarang berdasarkan data-data yang terjadi di lapangan. Jadi dalam penelitian ini penulis menggunakan metode penelitian deskriptif kualitatif yang bertujuan untuk mengungkap fakta, keadaan, fenomena, variabel dan keadaan yang terjadi saat penelitian berjalan dan menyajikan data-data apa adanya sehingga penelitian mendapatkan hasil penelitian yang sebenarnya dan dapat mengungkapkan permasalahan yang terjadi dalam perusahaan. Penelitian dilaksanakan pada saat penulis melaksanakan Praktek Darat (PRADA) pada bagian Procurement Department di Gold Bridge Shipping Ltd, selama 11 (sebelas) bulan terhitung mulai pada tanggal 27 Juli 2016 sampai dengan 30 Agustus 2017. Adapun keterangan tempat yang digunakan penulis melakukan penelitian di Gold Bridge Shipping Ltd. Alamat kantor di C/O : PT Berlian Laju Tanker Tbk. Wisma BSG $10^{\text {th }}$ Floor Jl. Abdul Muis No. 40 Jakarta 10160, Indonesia +62-3006$0300 /+6230060391$.

\section{A. Data Yang Diperlukan}

Dalam penyusunan skripsi ini penulis memerlukan beberapa sumber data, yang dimaksud sumber data adalah dari mana data diperoleh atau semua informasi, baik dari yang merupakan benda nyata, sesuatu yang abstrak, maupun peristiwa yang terjadi pada waktu penulis melakukan praktek darat. Dalam penulisan skripsi ini penulis banyak mengumpulkan data, adapun jenis data yang dapat dikumpulkan adalah sebagai berikut:

1. Data Primer

Menurut Widoyoko P. Eko (2012:22) menguraikan bahwa data primer adalah data yang diperoleh darisumber pertama, atau dengan kata lain data yang pengumpulannya dilakukan sendiri oleh peneliti secara langsung dan diolah sendiri oleh peneliti langsung dari responden atau subyek penelitian Procurement Department di Gold Bridge Shipping Ltd. Dlam penelitian ini data primer yang digunakan oleh penulis dalam penelitian ini adalah :

a. Hasil Observasi secara langsung yaitu di Gold Bridge Shipping Ltd

b. Hasil Wawancara (Interview) dengan narasumber

\section{Data Sekunder}

Menurut Widoyoko P. Eko (2012:22) juga mengatakan bahwa data sekunder adalah data yang diperoleh dari sumber kedua dan tidak terlibat secara langsung atau data yang telah diolah lebih lanjut ataupun disajikan oleh pihak lain. Data ini diperoleh secara tidak langsung.
Dalam penelitian ini penulis mempunyai data sekunder yang digunakan oleh penulis yaitu sebagai berikut:

a. Arsip-arsip dokumen terkait dengan masalah penelitian. Penulis memperoleh dokumendokumen Procurement Department dan prosedur mengajuan purchasing di Gold Bridge Shipping Ltd.

b. Referensi dari buku-buku dan beberapa literature karya ilmiah yang mendukung dalam penyusunan penelitian ini.

\section{B. Metodologi Pengumpulan Data}

Menurut Sugiyono

(2012:194)

menguraikan bahwa metode pengumpulan data dapat diperoleh dari hasil wawancara (interview), observasi, dan dokumentasi.

Di dalam penelitian ini penulis menggunakan beberapa teknik pengumpulan data antara lain :

1. Interview ( wawancara )

Menurut Lexy J. Moloeng (2015:186), menjelaskan bahwa wawancara adalah percakapan dengan maksud tertentu, percakapan itu dilakukan oleh dua pihak yaitu pewawancara (interviewer) yag mengajukan pertanyaan dan terwawancara (interviewee) yang memberikan jawaban atas pertanyaan itu. Dalam wawancara yang digunakan dalam penelitian ini adalah wawancara terbuka, peneliti bertanya langsung kepada narasumber yang dipili yaitu piha-pihak yang berkaitan, yaitu :

a. Bapak Barzilai Betshaida Pudya N selaku Junior Manager dari Procurement Department.

b. Ibu Dhilla Dwi Komara selaku Admin di Procurement Department.

2. Metode Observasi

Menurut Widoyoko P. Eko (2012:46) menjelaskan bahwa observasi adalah proses pengamatan dan pencatatan secara sistematik terhadap unsur-unsur yang nampak dalam suatu gejala pada objek penelitian. Unsur-unsur yang nampak itu disebut dengan data atau informasi yang harus diamati dan dicatat secara benar dan lengkap.

Dalam melakukan pengamatan penulis menjadi partisipan maka penulis berperan sebagai pengamat partisipatif yaitu terlibat dalam kegiatan penelitian. Pengamatan ini dilakukan dengan mengamati kejadian-kejadian dan sekaligus melaksanakan kegiatan dalam pelayanan Procurement Department sehingga penulis dapat menentukan narasumber yang 
akan memberikan informasi tentang gambaran permasalahan.

3. Dokumentasi

Menurut Widoyoko P. Eko (2012:46) menyimpulkan bahwa metode ini merupakan suatu cara pengumpulan data yang dilakukan dengan menganalisis isi dokumen yang berkaitan dengan masalah yang diteliti. Dalam arti sempit dokumen berarti barang-barang atau benda-benda tertulis, sedangkan dalam arti yang lebih luas, dokumen bukan hanya berwujud tulisan saja, tetapi dapat berupa benda-benda peninggalan seperti prasasti dan simbol-simbol lainnya.

Dalam penelitian ini penulis memperoleh data berupa arsip-arsip dokumen dari obyek penelitian yang menyangkut dengan permasalahan dalam penelitian ini, penulis menggunakan data dari perusahaan berupa data pembelian suku cadang kapal, data supplier, spare part list, purchase order, Sales, Contract, Invoice, Voucher Payment.

4. Studi pustaka

Studi pustaka ini bertujuan untuk mengumpulkan data dan informasi dengan bantuan yang terdapat di perpustakaan yang ada kaitannya dengan materi yang dibahas dalam penyusunan skripsi, dengan mempelajari bukubuku, ketentuan-ketentuan resmi yang berhubungan obyek permasalahan. untuk lebih memperkaya isi dari penyusunan skripsi ini, maka penyusun melakukan penelitian telaah kepustakaan yang khususnya terdapat di perpustakaan Politeknik Ilmu Pelayaran Semarang dan perpustakaan daerah Semarang yang diharapkan mampu mendapatkan informasi-informasi yang mendukung dan berhubungan dengan pokok permasalahan yaitu Peraturan dari Standart Operation Gold Bridge Shipping Ltd berupa Keputusan Direksi ISM Policy and Manual Book Nomor OS-0701 Tahun 2014 tentang prosedur Procurement.

\section{Teknik Analisis Data}

Menurut Sugiyono (2012:334), analisis data adalah proses mencari dan menyusun data secara sistematis yang diperoleh dari hasil wawancara, catatan lapangan, dan dokumentasi, dengan cara mengorganisasikan data ke dalam bentuk kategori, menjabarkan ke dalam unitunit, melakukan sintesa, menyusun kedalam pola, memilih yang penting dan yang akan dipelajari, serta membuat kesimpulan sehingga lebih mudah dibaca, dipahami, dan diinterpretasikan oleh diri sendiri maupun orang lain. Dalam penelitian ini penulis menggunakan lebih dari satu teknik analisis data, berikut adalah teknik analisis data yang digunakan oleh penulis dalam penelitian ini yaitu sebagai berikut :

\section{Reduksi Data}

Pada tahap reduksi data penulis akan memilih hal-hal pokok, memanfaatkan pada hal-hal yang penting dan membuang data yang tidak diperlukan. Dengan demikian data yang telah di reduksi akan memberikan gambaran lebih jelas mengenai permasalahan penelitian ini.

2. Penyajian Data

Pada tahap ini penulis menyajikan data berua sekumpulan informasi yang telah tersusun secra terpadu dan mudah dipahami yang memberikan kemungkinan adanya penarikan kesimpulan dan pengambilan tindakan.

3. Penarikan kesimpulan dan verifikasi

Tahap ini dimaksudkan untuk mencari makna data yang dikumpulkan dengan mencari hubungan, persamaan, atau perbedaannya. Penarikan kesimpulan dilakukan dengan jalan membandingkan kesesuaian pernyataan dari subyek penelitian dengan makna yang terkandung dengan konsep-konsep dasar dalam penelitian tersebut.

\section{HASIL DAN PEMBAHASAN}

\section{A. Gambaran Umum Obyek Yang Diteliti}

1. Sejarah Singkat Gold Bridge Shipping Ltd

Gold Bridge Shipping Ltd merupakan anak perusahaan dari PT. Berlian Laju Tanker Tbk yang pada mulanya berdiri dengan nama PT. Baitha Laju Tanker pada tahun 1981. Perusahaan yang memliki dua kapal tanker minyak pada saat itu yaitu MT. Brotojoyo dan MT. Anjasmoro dengan bobot total sebesar 12.050 DWT. Kedua kapal tersebut disewakan kepada Pertamina yang sekaligus menjadi tonggak awal hubungan bisnis perusahaan dengan Pertamina bahkan dikenal sebagai $a$ leading tanker operator in the world. Pada tahun 1988, perusahaan resmi berganti nama menjadi PT. Berlian Laju Tanker Tbk (BLTA).

PT. Berlian Laju Tanker juga meningkatkan jaringan di seluruh dunia dengan pendirian anak perusahaan, antara lain: GBLT UK Shipmanagement (UK) di Glasgow, GBLT Shipmanagement Pte Ltd di Singapore, dan Gold Bridge Shipping Ltd di Hongkong. Untuk mendukung jaringannya itu, PT. Berlian Laju Tanker juga memiliki kantor operasional di 
Singapura, Hongkong, Taiwan, Bangkok, Shanghai, Beijing, Behai, Mumbai, Westport selain itu terdapat juga kantor-kantor pemasaran di Dubai untuk melayani pelanggan di Asia Selatan, di Glasgow untuk melayani pelanggan di Eropa serta Westport-Conneticut, dan di Sao Paolo-Brasil untuk melayani pelanggan di Amrika Utara dan Amerika Selatan. Dengan mengakuisisi Chembulk Tankers LLC ("Chembulk") dari Amerika Serikat di tahun 2007. Perusahaan mampu menyediakan jasa transportasi keseluruh dunia termasuk Eropa, Baltik, Amerika, Asia Timur, Asia Tenggara, Asia Selatan, Timur Tengah serta Australia. Selain itu PT. Berlian Laju Tanker juga memiliki Asean Maritime Corporation yang diambil alih pada tahun 1998, beserta anak perusahaannya Gold Bridge Shipping Corporation.

Gold Bridge Shipping Ltd (GBS) didirikan di Hong Kong pada tahun 1990, dan sejak Agustus 2016 membuka kantor operasionlnya di Jakarta berdampingan dengan PT. Berlian Laju Tanker dengan semboyan " BLT and GBS under the same roof". Sebagai Perusahaan Manajemen Kapal, GBS menawarkan berbagai layanan pengelolaan kapal untuk Tanker Minyak, Kimia, dan Gas. GBS adalah perusahaan dengan sistem manajemen yang memenuhi syarat yang sejalan dengan mottonya; "Kirim dengan Keamanan dan Perawatan".

GBS dikelola oleh sekelompok profesional yang sangat terampil, berpengalaman, dan berdedikasi tinggi. Tim gabungan memiliki pengalaman bertahun-tahun dengan latar belakang teknis, pengiriman dan operasional, mampu menangani semua kompleksitas dalam manajemen armada.

Sebagai perusahaan pelayaran kelas dunia, PT. Berlian Laju Tanker sangat memahami bahwa kondisi armada yang dimiliki menentukan peluang keberhasilan bisnis perusahaan di tengah kompetisi global. Hampir seluruh kapal yang dimiliki oleh perusahaan merupakan kapal lambung ganda (double hull) dan seluruh armada kapal tanker kimia perusahaan telah memenuhi standar IMO II/III. Spesifikasi dari kapal-kapal yang dimiliki oleh perusahaan juga didukung dengan perwira dan awak kapal terlatih, selain itu sistem perawatan kapal dan permesinan kapal yang digunakan adalah barang-barang yang berkualitas. Hingga tahun 2011 perusahaan telah mengoperasikan 84 kapal tanker berbobot sekitar 2,2 juta DWT.
Melalui semboyan "Kirim dengan Keamanan dan Perawatan" senantiasa berkomitmen untuk memberikan pelayanan bemutu, terbaik, dn merata kepada setiap pelanggannya. Komitmen ini mewujudkan melalui pemenuhan standar keselamatan internasional (Internasional Safety Management Code/ ISM Code) dan standar ISO 9001:2000, standar OHSAS 18001:1999 dimana perusahaan telah memperoleh sertifikat dari lembagalembaga internasional tersebut. Komitmen perusahaan untuk memberikan pelayanan terbaik dan mematuhi standar tertinggi diyakini akan dapat menjamin kelangsungan bisnis perusahaan hingga masa mendatang.

2. Struktur Organisasi

Struktur organisasi adalah sekumpulan komponen-komponen (unit-unit kerja) yang telah disusun dalam organisasi. Struktur organisasi berguna untuk menunjukkan adanya beberapa pembagian kerja dan menunjukkan bagaimana fungsi-fungsi atau kegiatan-kegiatan yang berbeda-beda agar bisa dikoordinasikan.

Strukur organisasi dan tata kerja perusahan Gold Bridge Shipping Ltd hanya terbatas pada Procurement Department saja terkait dengan judul dan topic yang penulis bahas. Dimana tata kerjanya dipimpin oleh Procurement Manager yang bertanggung jawab kepada Technical GM dengan tugas utama yaitu: Untuk merencanakan, mengorganisir, mengontrol, dan mengevaluasi semua aktivitas dalam melayani penerimaan dan pengiriman suku cadang kapal dari supplier dan keatas kapal sesuai dengan visi, misi, serta sasaran hasil. Serta tanggung jawabnya adalah :

a. Menyiapkan perencanaan bisnis pegadaan suku cadang tahunan yang didasarkan pada misi dan tujuan perusahaan.

b. Memonitori dan menjajaki implemantasi dan kemajuan rencana pengadaan barang.

c. Membantu manajer direktur dalam menyampaikan laporan tahuanan pengadaan suku cadang kapal ke dewan direktur PT. Berlian Laju Tanker Tbk.

d. Membantu manajer direktur dalam mencapai tujuan perusahaan yang berhubungan dengan aktivitas penegadaan suku cadang kapal.

e. Menjadi suatu peran aktif membentuk standar professional yang paling tinggi, etika dan pengurusan kearah atasan, klien, dan karyawan lain.

f. Mendayagunakan para bawahan memenuhi peran mereka dalam memelihara bisnis professional. 
Dalam menjalankan tugas-tugas dan tanggung jawabnya, Procurement Manager dibantu oleh beberapa staf Procurement. Dimana tugas utamanya adalah untuk memastikan semua aktivitas pengadaan suku cadang kapal berjalan sesuai dengan rencana, untuk mengembangkan kerjasama dengan supplier, membantu manajer Procurement dalam segala aktivitas kerja Procurement Department.

Guna menjalankan kewajibannya. Staf Procurement Department sendiri terbagi menjadi sub-divisi antara lain :

\section{1). Procurement Junior Manager}

Procurement Junior Manager dapat dikatakan sebagai asisten atau wakil dari Procurement Manager yang mempunyai peran membantu tugas rutin dari seorang manajer serta mempertanggung jawabkan tugasnya kepada Procurement Manager juga Bertanggung jawab atas pengadaan barang atau suku cadang pada kapal-kapal yang dioperasikan oleh PT. Berlian Laju Tanker Tbk., baik yang beroperasi didalam negeri ataupun diluar negeri. Operation staff bertugas membuat Purchase Order, melayani pemesanan suku cadang kapal sesuai lembar Requisition (permintaan kapal) melakukan negosisasi pemesana barang barang kepada supplier

2). Procurement Superintendent

Superintendent adalah orang yang menangani semua kapal milik perusahaan, menganalisa kerusakan kapal baik dari hasil survey lapangan ataupun dari laporan crew kapal, memberikan saran \& monitoring perbaikan kapal, menganalisa kebutuhan Spare Part untuk melakukan perbaikan kapal, bertanggung jawab untuk menjaga semua sertifikat kelas \& BKI, Membuat laporan (harian, mingguan, bulanan).

\section{3).Operation Staff}

Mempunyai tanggung jawab melaporkan jadwal trayek kapal dan posisi kapal perusahaan dimana untuk membantu proses pengiriman suku cadang kapal keatas kapal.

4). Staff Administrasi Procurement

Bertanggung jawab pada kelancaran dan keakuratan data pada Procurement Department. Staf Administrasi memiliki tugas mencatat dan memeriksa seluruh data pembelian dari supplier, membuat voucher payment sebagai tagihan atas pembelian barang serta menangani arsip-arsip contohnya Purchase Order dan kontrak sementara dengan para Supplier.

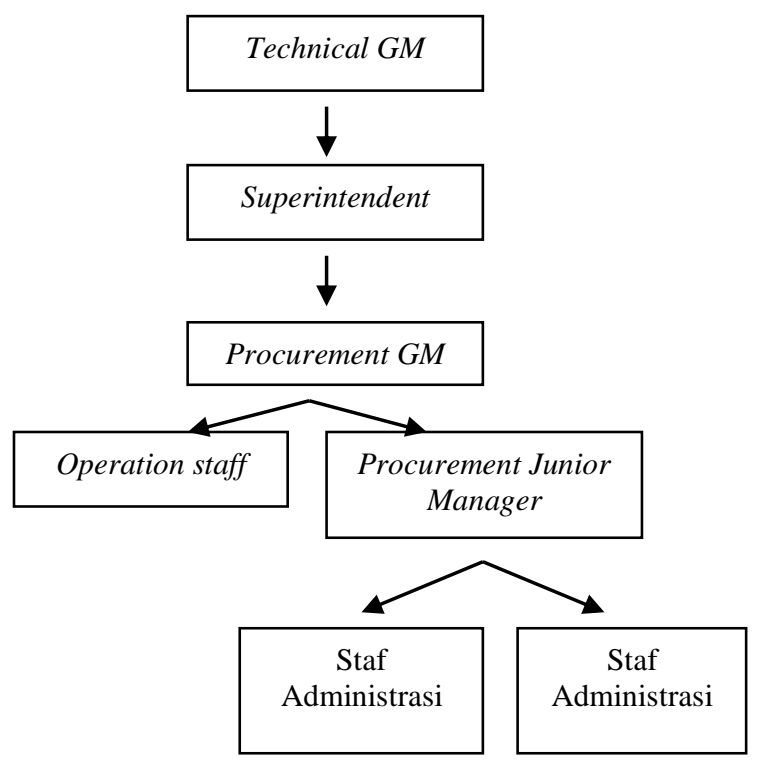

Gambar Struktur Organisasi Procurement Department

\section{B. Analisis Hasil Penelitian}

Dalam pelayanan penyediaan suku cadang Procurement Department mempunyai 3 buah komputer pelayanan. Dimana setiap komputer mempunyai tugas masing-masing. Komputer pertama digunakan untuk pelayanan e-mail masuk dari kapal yang mengirim permintaan barang (Requisition) yang akan diperiksa oleh superintendent kebutuhan kapal yang akan dikirimkan. Komputer kedua digunakan untuk membuat penawaran (Quotation) yang akan dikirimkan ke Supplier jika ada harga, jumlah, dan spesifikasi barang yang cocok akan dibuatkan Purchase Order yang menandakan bahwa barang jadi untuk dibeli perusahaan. Komputer ketiga digunakan untuk memproses seluruh Invoice yang masuk untuk dibuatkan Payment Voucher yang akan dikirim ke bagian Accounting untuk dilakukan proses pembayaran. Kemudian dicatat dalam daftar pengeluaran barang. Dalam setiap kegiatan pelayanan penyediaan suku cadang sangat diperlukan sistm komputerisasi untuk mempermudah dan menyingkat waktu pengerjaan seluruh dokument tersebut.

Melalui analisis-analisis didapatkan masalah-masalah yang pada akhirnya akan dibahas pada pembahasan masalah. Pendekatan masalah yang penulis kemukakan adalah sebagai berikut: 


\section{Kinerja Procurement Department dengan menggunakan sistem komputerisasi.}

Dalam setiap kegiatan penyediaan suku cadang di Procurement Department sistem kompterisasi sangat dibutuhkan dan membantu kinerja staf tanpa sistem komputerisasi akan menghambat seluruh kegiatan penyediaan suku cadang. Berdasarkan pengamatan yang penulis lakukan pada kegiatan pelayanan penyediaan suku cadang kapal di Gold Bridge Sipping Ltd, penulis melihat beberapa keuntungan yang didapat dalam penggunaan sistem komputerisasi di Procurement Department, diantaranya yaitu :

a. Penyimpanan data suku cadang kapal lebih efektif dan efisien.

Data suku cadang kapal yang dikirim akan tersimpan di dalam database komputer. Hal ini akan mempermudah pencarian data secara cepat jika dibutuhkan sewaktu-waktu dan tidak membutuhkan ruang yang banyak.

Serta akan terhindar dari hama rayap.

b. Dokumen lebih rapi dan mudah terbaca.

Bila pencatatan segala dokumen dan daftar suku cadang yang disimpan menggunakan tulisan tangan atau manual, biasanya akan sulit dibaca oleh orang lain. Kerapian tulisannya pun juga belum pasti.

c. Proses pengerjaannya cepat dan praktis.

Dengan menggunakan sistem komputerisasi staf Procurement Department tidak perlu lagi memikirkan kerapian tulisan sehingga tidak menghabiskan waktu yang lama dalam pengerjaan 1 (satu) dokumen. Jika mencatat dokumen dengan manual dalam 1 (satu) hari hanya menghasilkan sedikit dokumen, dengan adanya sistem komputerisasi yang praktis dapat membantu pekerjaan staf menjadi lebih cepat.

d.Accounting dan Procurement Department sudah saling terhubung.

Dengan adanya sistem $B$-One ini memudahkan terhubungnya Procurement Department dengan Accounting mengenai masalah tagihan pembayaran sehingga Procurement Department tidak perlu memikirkan lagi masalah keuangan, misalnya jika staf Procurement Department sudah membuat Payment Voucher kemudian dikirim kepada Accounting lewat sistem B-One maka seluruh masalah tagihan pembayaran akan diselesaikan oleh Accounting.

e. Proses Pencarian dokumen menjadi lebih cepat

Dengan adanya sistem komputerisasi mempermudah staf untuk melakukan pencarian dokumen yang tersimpan di sistem database sehingga dibutuhkan secara tiba-tiba tidak memerlukan waktu yang lama untuk mencarinya.

\section{Kinerja Procurement Department dengan} tidak menggunakan sistem komputerisasi.

a. Penyimpanan data suku cadang kapal tidak efektif dan efisien

Jika Data suku cadang kapal yang dikirim tidak di simpan di dalam database komputer. Hal ini akan memperlambat pencarian data secara cepat jika dibutuhkan sewaktu-waktu akan sangat lama untuk mencarinya karena banyaknya dokumen dan akan membutuhkan ruang yang banyak serta tidak terhindar dari hama rayap karena tersimpan didalam lemari dalam jangka waktu yang lama.

b. Dokumen tidak tercatat dengan lengkap

Dokumen dalam perusahaan penyediaan suku cadang di kapal sangatlah banyak dan rinci, oleh karena itu sangat di butuhkan sistem komputerisasi karena dapat membantu dalam hal pencatatan dan pengecekan daftar barang yang akan disediakan

c. Perhitungan tidak akurat

Dalam proses Procurement Department dalam penyedian suku cadang ada beberapa pencatatan dokumen daftar barang yang harus dihitung dan dibandingkan harga barang sebelum dibeli dari supplier maka dibutuhkan perhitungan yang akurat dari sistem komputer karena keterbatasan ketelitian manusia.

d. Proses Pencarian dokumen lambat

Jika tidak ada sistem komputerisasi staf akan mengalami kesulitan untuk melakukan pencarian dokumen sehingga jika ada dokumen yang dibutuhkan secara tiba-tiba memerlukan waktu yang lama untuk mencarinya karena sudah tertumpuk dengan dokumen yang baru.

\section{Perbandingan kinerja Procurement Department tidak penggunaan sistem komputerisasi dan menggunakan sitem komputerisasi.}

Dalam hal ini penulis mengamati perbandingan kinerja staf Procurement Department pada saat bekerja dengan menggunakan sistem komputerisasi dan tidak menggunakan menggunakan sistem komputerisasi, dan hasilnya dapat dilihat pada Tabel 4.1. 
Pada Tabel 4.1 diatas menunjukkan hasil perbandingan kinerja staf procurement department dengan menggunakan sistem work standart. Dimana sistem ini digunakan oleh perusahaan dalam mengukur kinerja Procurement Department. Tabel diatas menunjukkan klasifikasi hasil pekerjaan yang dilakukan staf mengerjakan dokumen dengan menggunakan sistem komputerisasi dan tidak menggunakan sistem komputerisasi yang dilakukan staf berupa angka presentase yang di peroleh dari pengukuran hasil pekerjaan dalam satu hari.

Hasil Perbandingan Kinerja Staf Menggunakan Sistem Komputerisasi Dan Tidak Menggunakan Sistem

$$
\text { Komputerisasi }
$$

\begin{tabular}{|c|c|c|c|c|}
\hline & $\begin{array}{l}\text { Angka } \\
\text { Efekti- } \\
\text { vitas } \\
\text { Menindak } \\
\text {-lanjuti } \\
\text { pesanan }\end{array}$ & $\begin{array}{l}\text { Membuat } \\
\text { Purchase } \\
\text { Order }\end{array}$ & $\begin{array}{l}\text { Negosiasi } \\
\text { dengan } \\
\text { supplier }\end{array}$ & $\begin{array}{l}\text { Rekapitu } \\
\text { lasi } \\
\text { Invoice } \\
\text { (Voucher } \\
\text { Payment) }\end{array}$ \\
\hline $\begin{array}{l}\text { Ideal } \\
\text { Target }\end{array}$ & $\begin{array}{l}1 \text { hari } \\
\text { selesai }\end{array}$ & $10 \mathrm{PO}$ & $\begin{array}{l}10 \\
\text { Supplier }\end{array}$ & $10 \mathrm{VP}$ \\
\hline $\begin{array}{l}\text { Staf I } \\
\text { (Mengguna- } \\
\text { kan } \\
\text { Komputer) }\end{array}$ & $\begin{array}{l}1 \text { hari } \\
\text { selesai }\end{array}$ & $10 \mathrm{PO}$ & $\begin{array}{l}10 \\
\text { supplier }\end{array}$ & $10 \mathrm{VP}$ \\
\hline $\begin{array}{l}\text { Staf II } \\
\text { (Tidak } \\
\text { Mengguna- } \\
\text { kan } \\
\text { Komputer) }\end{array}$ & $\begin{array}{l}2 \text { hari } \\
\text { selesai }\end{array}$ & $7 \mathrm{PO}$ & 6 supplier & $5 \mathrm{VP}$ \\
\hline
\end{tabular}

Keterangan:

$\mathrm{PO}=$ Purchase order

$\mathrm{VP} \quad=$ Voucher Payment

Dari data tersebut dapat dilihat bahwa hasil kinerja staf Procurement Department menindak lanjuti pesanan dari Technical Superintendent hasilnya lebih banyak menggunakan sistem komputerisasi yaitu dengan Ideal Target dapat mengerjakan dokumen sebanyak 10 (sepuluh) dokumen dalam 1 (satu) hari dapat tercapai. Sedangkan jika tidak menggunakan sistem komputeisasi tidak mencapat Ideal Target perusahaan. Dengan data pada Tabel 4.1 disimpulkan bahwa kinerja staf Procurement Department lebih baik dan mencapai target dengan bantuan sistem komputerisasi yang berpengaruh dengan cepatnya dokumen akan segera diproses jika selesai tepat waktu.
Untuk menguatkan hasil pengamatan atau observasi yang peneliti lakukan tentang kendala yang dihadapi dalam penggunaan sistem komputerisasi di pelayanan penyediaan suku cadang di Procurement Department di Gold Bridge Shipping Ltd, penulis melakuan wawancara perbandingan penggunaan system komputerisasi dengan Junior Manager Procurement Department bapak Barzilai Betshaida yang pada intinya mengatakan bahwa "Ada beberapa kegiatan pencatatan dalam penyediaan suku cadang masih pencatatan secara manual sehingga membuat staff harus sering memeriksa barang di tempat penyimpanan untuk selalu di update." dan staf Procurement Department yaitu Ibu Dilla Dwi Komara yang mengatakan bahwa "Jika sistem $B$-One tidak ada, maka akan sangat menghambat kerja para staf, karena dengan sistem komputerisasi memudahkan mencari bukti-bukti transaksi yang belum atau yang telah ,dan yang akan dilakukan. Namun dengan beberapa kali terjadi gangguan koneksi yang memungkin berhentinya kegiatan pembuatan Voucher Payment sangat mengganggu kinerja staff dan perlu diperbaiki servernya.

Berdasarkan hasil pengamatan atau observasi dapat dijelaskan tentang keuntungan yang didapat dalam penggunaan sistem komputerisasi pada Procurement Department di Gold Bridge Shipping Ltd, peneliti melakuan wawancara mengenai keuntungan menggunakan system komputerisasi di Gold Bridge Shipping Ltd yaitu diantaranya dengan Junior Manager Procurement Department bapak Barzilai Betshaida yang mengatakan bahwa "Dengan adanya sistem komputerisasi ini, Data suku cadang kapal yang dikirim akan tersimpan di dalam database komputer dan penyimpanan data menjadi lebih efektif dan efisien." dan staf Procurement Department yaitu Ibu Dilla Dwi Komara yang pada intinya mengatakan bahwa "Dengan sisitem komputerisasi dokumen lebih mudah untuk dibaca dan rapi. Selain itu proses pengerjaan Purchase Order dan Payment Voucher menjadi lebih cepat.".

Dengan hasil wawancara diatas tersebut dapat disimpulkan bahwa sistem komputerisasi sangat membantu dalam kinerja staf Procurement Department secara efektif dan efisien dan mempermudah seluruh kegiatan penyediaan suku cadang.

\section{Pembahasan Masalah}

Berdasarkan hasil analisis yang telah diuraikan diatas dan identifikasi masalah yang 
ada, maka pembahasan masalah sebagai berikut:

1. Keuntungan yang didapat bila menggunakan sistem komputerisasi didalam Procurement Department.

a. Penyimpanan data suku cadang kapal lebih efektif dan efisien.

Data suku cadang kapal yang dikirim akan tersimpan di dalam database komputer. Hal ini akan mempermudah pencarian data secara cepat jika dibutuhkan sewaktu-waktu lebih praktis untuk mencarinya dan tidak membutuhkan ruang yang banyak serta akan terhindar dari hama rayap.

b. Dokumen lebih rapi dan mudah terbaca.

Bila pencatatan segala dokumen dan daftar suku cadang yang disimpan menggunakan tulisan tangan atau manual, biasanya akan sulit dibaca oleh orang lain. Kerapian tulisannya pun juga belum pasti.

c. Proses pengerjaannya cepat dan praktis.

Para staf Procurement Department tidak perlu memikirkan kerapian tulisan. Hal ini juga akan membuat proses pengerjaan membutuhkan waktu yang lama.

d.Accounting dan Procurement Department saling terhubung.

Dengan adanya sistem B-One ini memudahkan terhubungnya Procurement Department dengan Accounting mengenai masalah tagihan pembayaran sehingga Procurement Department tidak perlu memikirkan lagi masalah keuangan sehingga Procurement Department tidak perlu memikirkan lagi masalah keuangan, misalnya jika staf Procurement Department sudah membuat Payment Voucher kemudian dikirim kepada Accounting lewat sistem B-One maka seluruh masalah tagihan pembayaran akan diselesaikan oleh Accounting

e. Proses Pencarian dokumen menjadi lebih cepat

Dengan adanya sistem komputerisasi mempermudah staf untuk melakukan pencarian dokumen yang tersimpan di sistem database sehingga jika ada dibutuhkan secara tiba-tiba tidak memerlukan waktu yang lama untuk mencarinya.

2. Kendala yang dihadapi dalam penggunaan sistem komputerisasi di Procurement Department

a. Spesifikasi komputer yang digunakan.

Spesifikasi komputer yang digunakan sudah sesuai dengan menggunakan komputer dengan processor Intel Core 2 Duo. Namun dengan bertambahnya dokumen setiap harinya akan mempengaruhi kemampuan dari komputer itu sendiri. Maka hal yang harus dilakukan yaitu memperbarui spesifikasinya. Salah satu contohnya yaitu memperbarui processor dari Intel Core I3, menjadi Intel Core I7. Penambahan spesifikasi ini akan berpengaruh pada proses pengerjaan dokumen menjadi lebih cepat.

b. Kerusakan sistem komputer itu sendiri.

Setiap harinya jumlah dokumen akan terus bertambah. Maka, sistem software dan hardware juga akan terpangaruh dengan kinerjanya. Perawatan komputer harus dilakukan secara berkala sesuai kebutuhan, namun tetap wajib dilakukan. Hal ini bertujuan untuk mengetahui kondisi terbaru dari sistem komputer. Pembaruan sistem windows dari windows 7 ke windows 10 sangat dianjurkan untuk menambah kemampuan kecepatan komputer.

c. Sistem $B$-One sering hang.

Sistem ini sudah baik untuk menghubungkan Procurement Department dengan Accounting tetapi pada sistem ini kurang lengkap dan beberapa kali terjadi gangguan koneksi yang memungkin berhentinya kegiatan pembuatan Voucher Payment dan menghambat proses keuangan. Dari masalah tersebut sebaiknya IT lebih memperhatikan jaringan koneksi pada sistem B-One karena banyak transaksi yang harus dicatat dalam sistem ini.

d. Kerusakan komponen komputer.

Semakin lama komputer digunakan, maka semakin turun kualitasnya. Faktor lain juga dikarenakan semakin banyaknya dokumen suku cadang kapal yang harus dicatat dan dimasukkan setiap harinya. Atau mungkin memang sudah waktunya diganti. Pada saat pengecekan komponen, sebaiknya membuat laporan daftar kerusakan komponen.

e. Kurangnya sumber daya manusia bidang teknologi informasi.

Jumlah staf bidang IT di PT. Berlian Laju Tanker Tbk hanya ada 3 (tiga) orang saja. Faktanya di semua departemen yang ada di PT. Berlian Laju Tanker Tbk dan Gold Bridge Shipping Ltd sering membutuhkan staf bidang IT sehingga jika IT nya tidak di tempat harus menunggu dan membuat pekerjaan tertunda. Sebaiknya menambah 1 (satu) staf atau 2 (dua) staf untuk membantu 
jika terjadi banyak komputer trouble pada hari yang bersamaan.

Secara ilmiah, setiap pernyataan tentang kekurangan atau kelebihan pegawai harus menggunakan parameter atau tolok ukur. dalam teori manajemen personalia, disebutkan bahwa angka kecukupan personil harus didasarkan analisis beban kerja. Berkaitan hal ini penulis mencari data ke bagian personalia. Berdasarkan wawancara dengan Ibu Tauristya Suci selaku staf kepegawaian diperoleh informasi bahwa setiap pegawai harus mampu bekerja minimal 40 (empat puluh) jam semiggu. Lembur atau overtime dibenarkan maksimal 10 (sepuluh) jam per minggu dengan balas jasa atau imbalan. Apabila satu minggu seorang pegawai bekerja lebih dari 40 (empat puluh) plus 10 (sepuluh), ini mengindikasikan perusahaan itu perlu melakukan rekruitmen SDM baru. Sebab bila dipaksakan dapat berakibat kesalahan bertugas (kinerja banyak yang salah, dsb.

f. Sistem komputerisasi belum sepenuhnya diterapkan.

Ada beberapa kegiatan pencatatan dalam penyediaan suku cadang masih pencatatan secara manual sehingga harus sering memeriksa barang di tempat penyimpanan untuk selalu di update.

3. Kendala yang dihadapi jika tidak penggunaan sistem komputerisasi di Procurement Department

a. Dokumen tidak tercatat secara lengkap

Dokumen dalam perusahaan penyediaan suku cadang di kapal sangatlah banyak dan rinci, oleh karena itu sangat di butuhkan sistem komputerisasi karena dapat membantu dalam hal pencatatan dan pengecekan daftar barang yang akan disediakan.

b. Perhitungan tidak akurat

Dalam proses Procurement Department dalam penyedian suku cadang ada beberapa pencatatan dokumen daftar barang yang harus dihitung dan dibandingkan harga barang sebelum dibeli dari supplier maka dibutuhkan perhitungan yang akurat dari sistem komputer karena keterbatasan ketelitian manusia.

c. Proses Pencarian dokumen lama

Jika tidak ada sistem komputerisasi staf akan mengalami kesulitan untuk melakukan pencarian dokumen sehingga jika ada dokumen yang dibutuhkan secara tiba-tiba memerlukan waktu yang lama untuk mencarinya karena sudah tertumpuk dengan dokumen yang baru.

4. Upaya-upaya untuk mengatasi kendala dalam penggunaan sistem komputerisasi adalah :

a. Melakukan pengadaan komputer baru sesuai dengan spesifikasi terbaru.

b.Pihak IT membuat back up data yang berlapis-lapis agar aman dari serangan virus dan para hacker.

c. Pihak Procurement Department sebaiknya segera mungkin berkoordinasi dengan pihak IT mengenai permasalahan system databasenya dan membenahi server agar tidak terjadi gangguan atau terputus koneksi internet secara tiba-tiba.

d. Sebaiknya melakukan rekruitmen staf bagian teknologi informasi sesuai dengan kebutuhannya. Minimal 1 (satu) orang staf IT agar saat dibutuhkan tidak menunggu antrian.

\section{A. Kesimpulan}

\section{PENUTUP}

1. Kinerja Procurement Department dengan menggunakan sistem komputerisasi adalah :

a. Penyimpanan seluruh dokumen suku cadang kapal menjadi lebih efektif dan efisien.

b. Accounting dan Procurement Department saling terhubung lebih mudah untuk berkoodinasi.

c. Perbandingan harga suku cadang kapal lebih akurat.

d. Proses pencarian dokumen lebih cepat.

2. Kinerja Procurement Department dengan tidak menggunakan sistem komputerisasi adalah :

a. Dokumen tidak tercatat dengan lengkap

b. Perhitungan dan perbandingan harga tidak akurat.

c. Pengerjaan dokumen menjadi lebih lama.

d. Proses pencarian dokumen lebih lama

\section{Perbandingan kinerja Procurement}

Department dengan menggunakan sistem komputerisasi dan tidak menggunakan sistem komputerisasi adalah :

a. Dokumen lebih rapi dan mudah terbaca dibandingkan jika tidak menggunakan sistem sehingga lebih tertata.

b. Proses pengerjaannya dokumen lebih cepat dan praktis dibandingkan dengan tidak menggunakan sistem komputerisasi karena jika manual pengerjaan dokumen dalam sehari hanya menghasilkan sedikit dokumen dibandingkan dengan menggunakan sistem komputerisasi. 
c. Accounting dan Procurement Department saling terhubung sehingga menjadi lebih mudah untuk berkoordinasi mengenai tagihan pembayaran.

d. Proses pencarian dokumen menjadi lebih cepat.dibandingkan dengan tidak menggunakan sistem komputer sehingga jika ada dokumen yang dibutuhkan secara tibatiba tidak memerlukan waktu yang lama untuk mencarinya karena sudah tertumpuk dengan dokumen yang baru.

B. Saran

Berdasarkan analisa dan pembahasan masalah yang dilakukan maka penulis dapat memberikan saran yaitu:

1. Keuntungan atau hal positif dalam penggunaan sistem komputerisasi sangat banyak, tetapi sebaiknya Procurement Department lebih memperhatikan pada halhal sebagai berikut:

a. Karena proses pengerjaannya yang cepat, petugas diharuskan lebih teliti dalam memasukan data suku cadang yang akan dikirim ke kapal agar meminimalisir kesalahan karena kesalahan sedikit saja bisa berakibat fatal untuk perusahaan dikemudian hari.

b. Staf Procurement Department sebaiknya sering meng-update daftar barang kedalam system database agar tercatat dan sesuai dengan kondisi lapangan.

2. Untuk mengatasi kendala yang ditemukan pada pelaksanaan Procurement Department di Gold Bridge Shipping Ltd sebaiknya :

a. Penyimpanan data suku cadang kapal tidak efektif dan efisien, sebaiknya Gold Bridge Shipping Ltd, meng-upgrade sistemnya agar lebih efektif dan efisien dalam pembuatan dokumen seperti menambah fitur pada sistem database management.

b. Pihak IT membuat back up data yang berlapis-lapis agar aman dari serangan virus dan para hacker.

c. Pihak Procurement Department sebaiknya segera mungkin berkoordinasi dengan pihak IT mengenai permasalahan system database-nya dan membenahi server agar tidak sering terjadi gangguan.

d. Melakukan training sebelum karyawan dari kapal ditugaskan di kantor agar tidak menghambat kinerja karyawan yang lain akibat tidak bisa mengoperasikan komputer.

3. Dalam menyikapi perbandingan penggunaan sistem komputerisasi, maka sebaiknya Gold
Bridge Shipping Ltd melakukan sebagai berikut :

a. Penyimpanan data suku cadang kapal menjadi lebih efektif tetapi sebaiknya harus tetap teliti dan hati-hati dalam mencatat data.

b. Dengan menggunakan sistem komputerisasi dokumen menjadi lebih rapi dan mudah terbaca, dibandingkan jika tidak menggunakan sistem sehingga lebih tertata. Tetapi sebaiknya staf Procurement Department tetap melakukan pengecekan ulang agar tidak terjadi kesalahan dalam memasukkan data.

\section{DAFTAR PUSTAKA}

Arifin, Hasnul. 2011. Kitab Suci Jaringan Komputer dan Koneksi Internet. Yogyakarta : Mediakom.

Fahmi, Irham. 2012. Analisis Kinerja Keuangan, Bandung: Alfabeta

Fakhri, Husein, Muhammad dan Wibowo Amin, 2011. Sistem Informasi Manajemen. UPP STIM YKPN Yogyakarta, Yogyakarta : STIM YKPN Yogyakarta.

Hasibuan, S.P. Malayu, H, 2014, Manajemen Sumber Daya Manusia, Edisi Revisi, Bumi Aksara: Jakarta.

Imawan. 2011. Step By Step Merancang dan Membangun Sistem Komputerisasi. Jakarta : Elexmedia Komputindo.

https://travel.kompas.com "Sejarah PT. Berlian Laju Tanker Tbk" 2009. Diakses tanggal 28 Februari 2018.

Juliandi. 2009. Pengenalan Dasar Komputer. Bandung, CV Cipta Dea Pustaka, Bandung

Keputusan Direksi Gold Bridge Shipping Ltd. ISM Policy and Manual Book Nomor SO-0701 Tahun 2014 tentang prosedur procurement.

Moekijat. 2009. Administrasi Kepegawaian Negara Indonesia. Mandar Maju, Bandung.

Moleong, Lexy J, 2015, Metodelogi Penelitiaan Kualitatif, PT. Remaja Rosdakarya Bandung.

Purwanto. 2008. Pelayanan Publik Partisipatif, Dalam Dwiyanto (Ed). Mewujudkan Governance Melalui Pelayanan Publik. Yogyakarta : Gajah Mada Press.

Sugiyono, 2012, Metode Penelitian Pendidikan, Alfabeta, Bandung.

Turban, E, Et al, 2010, Electronic Commerce: A managerial Perspective. New Jersey: Pearson prentice Hall, Inc.

Wahyono, Teguh. 2009. Etika Komputer + Tanggung Jawab Profesional di Bidang Teknologi Informasi.ANDI, Yogyakarata. 